\title{
Detección del virus de la necrosis pancreática infecciosa (IPNV) en sedimentos de agua dulce ${ }^{\#}$
}

\author{
Detection of infectious pancreatic necrosis virus (IPNV) in freshwater sediments \\ R Labraña, JC Espinoza, J Kuznar* \\ Laboratorio de Bioquímica y Virología, Departamento de Química y Bioquímica, Facultad de Ciencias, \\ Universidad de Valparaíso, Valparaíso. Chile.
}

\begin{abstract}
SUMMARY
Infectious pancreatic necrosis virus (IPNV) is a pathogen of great concern in salmon aquaculture producing high mortalities in fry. Water is the most important vehicle for horizontal transmission of the virus; therefore, sediments close to aquaculture facilities could become enriched reservoirs of the virus. We developed a simple and reliable method aimed at quantifying IPNV from sediments in salmon culture areas. IPNV is extracted in a sodium pyrophosphate solution and titrated in CHSE-214 cells through the fluorescent focus (FF) method. Results showed that IPNV can remain active in fresh water sediments for weeks and that the virus can be detected in environments with a previous history of IPNV outbreaks.
\end{abstract}

Palabras clave: virus IPN, acuicultura, sedimentos, epifluorescencia.

Key words: IPNV, sediments, aquaculture, epifluorescence microscopy.

\section{INTRODUCCION}

El virus de la necrosis pancreática infecciosa (virus IPN) es el agente etiológico de una enfermedad que causa importantes pérdidas en la industria chilena de la salmonicultura. El agua es un importante medio de transporte para el virus (Chamorro y col 2006). Estos, asociados a moléculas orgánicas, tejidos de peces infectados, fecas contaminadas, etc., pueden llegar a formar parte de capas sedimentarias formando un foco para posteriores infecciones (Suttle y Chen 1992, McAllister y col 1997). La perturbación de los sedimentos podría generar nuevos episodios de la enfermedad debido a la resuspensión de las partículas. Investigaciones previas han mostrado que los sedimentos marinos y los de agua dulce son importantes reservorios de virus debido a que estas capas pueden concentrar virus activo y crear un ambiente infeccioso preocupante para la industria y la salud pública (Lewis y col 1985, Lawrence y col 2002).

El virus IPN es estable en una amplia gama de condiciones de temperatura, $\mathrm{pH}$ y salinidad (Mortensen y col 1998), características que hacen del virus un candidato potencial para persistir en sedimentos tanto en agua dulce como de mar. Para explorar esta posibilidad es que esta investigación tiene dos objetivos principales: 1) Estandarizar un procedimiento para aislar y cuantificar virus IPN desde

Aceptado: 21.11.2007.

\# Financiamiento: DIPUV-12 2004 y CIGREN-UV.

* Gran Bretaña 1111, Playa Ancha, Valparaíso, Chile; juan.kuznar@ uv.cl sedimentos en agua dulce y 2) aplicar este método a muestras de sedimentos de pisciculturas con una historia de brotes de virus IPN.

\section{MATERIAL Y METODOS}

\section{CELULAS Y VIRUS}

Se emplearon células CHSE-214 (ATCC CRL 1681) mantenidas a $20^{\circ} \mathrm{C}$ en medio mínimo esencial (MEM), suplementado con sales de Earle, l-glutamina $2 \mathrm{mM}$, aminoácidos no esenciales $0,1 \mathrm{mM}$ (GIBCO, EE.UU.), bicarbonato de sodio $(2 \mathrm{mg} / \mathrm{ml})$, gentamicina $(50 \mu \mathrm{g} / \mathrm{ml})$ y $10 \%$ de suero fetal bovino (SFB) (Invitrogen, EE.UU.). Para realizar los análisis de inmunofluorescencia las células se cultivaron a $20{ }^{\circ} \mathrm{C}$ sobre cubreobjetos de vidrio de 12 $\mathrm{mm}$ de diámetro en microplacas de plástico de 24 pocillos o en placas Petri de $35 \mathrm{~mm}$ de diámetro.

El virus utilizado fue aislado y caracterizado en Chile y es idéntico al serotipo VR-299 (Espinoza y col 1985).

\section{CUANTIFICACION DE VIRUS IPN MEDIANTE FOCOS FLUORESCENTES (FF)}

Este método fue descrito por Espinoza y Kuznar (2002) y se utilizó para determinar los títulos virales. La titulación se realizó preparando diluciones seriadas en MEM con 2\% SFB. Alícuotas de $10 \mu \mathrm{l}$ se inocularon directamente sobre cultivos preconfluentes de células CHSE- 214 crecidas en cubreobjetos de vidrio. Tras $1 \mathrm{~h}$ de adsorción a $20^{\circ} \mathrm{C}$, el medio fue reemplazado por $1 \mathrm{ml}$ de medio fresco suplementado con $2 \%$ de SFB. 
Tras $16 \mathrm{~h}$, el medio fue removido y las células fueron fijadas con metanol a $-20{ }^{\circ} \mathrm{C}$ durante $10 \mathrm{~min}$. Posteriormente fueron lavadas con buffer fosfato salino PBS ( $\mathrm{NaCl} 137 \mathrm{mM} ; \mathrm{KCl} 2,7 \mathrm{mM} ; \mathrm{KH}_{2} \mathrm{PO}_{4} ; 1,5 \mathrm{mM}$; $\mathrm{Na}_{2} \mathrm{HPO}_{4} 8 \mathrm{mM}$ ) e incubadas con anticuerpo monoclonal (Am14) anti VP2 $(1 \mu \mathrm{g} / \mathrm{ml})$ durante $1 \mathrm{~h}$ a temperatura ambiente (TA). Las células fueron nuevamente lavadas con PBS e incubadas con anticuerpo secundario antiratón conjugado con FITC (Sigma, EE.UU.), 1/100 en PBS, por 30 minutos a TA. Luego de la incubación, las células fueron lavadas tres veces por 5 min con PBS y montadas con solución de montaje (Dako, Dinamarca). Las muestras teñidas fueron examinadas mediante un microscopio de epifluorescencia (Olympus BX60) con aumento de 100X. Para los resultados de la figura 1 se obtuvieron valores del orden de 1 x $10^{5} \mathrm{FF} / \mathrm{ml}$ y para los de la figura $2,1 \times 10^{2} \mathrm{FF} / \mathrm{ml}$.

\section{SEDIMENTO}

Para estandarizar un procedimiento de extracción de virus se utilizaron muestras control de sedimentos colectados en la Reserva Nacional Lago Peñuelas en Valparaíso. Estas fueron colectadas con cores de $5 \mathrm{~cm}$ de diámetro y $10 \mathrm{~cm}$ de penetración y guardadas a $4{ }^{\circ} \mathrm{C}$ hasta su análisis. El tamaño de los granos se mantuvo entre 8 y 4 × $10^{-3} \mathrm{~mm}$. Para definir un protocolo que permita separar el virus de los sedimentos, se prepararon muestras artificiales con sedimentos frescos que se centrifugaron a $1020 \mathrm{x} g$ durante 5 min para eliminar el agua de poro. $4 \mathrm{~g}$ de los sedimentos así preparados se mezclaron con $2 \mathrm{ml}$ de suspensiones conteniendo virus (2 $x 10^{6} \mathrm{FF} / \mathrm{ml}$ en PBS), tras homogeneizar manualmente, la mezcla se mantuvo a $4{ }^{\circ} \mathrm{C}$ durante 1 día. Al cabo de ese período de tiempo, la muestra se encuentra en dos fases, una sólida y otra líquida, esta última se remueve con una pipeta. Este sedimento estándar se usó para desarrollar un protocolo de extracción y se empleó además, referencialmente, como tiempo cero en el experimento de recuperación de virus.

Las muestras de campo se obtuvieron de sedimentos lacustres tomadas bajo balsas-jaula de dos sitios diferentes de una piscicultura con historia previa de episodios de la enfermedad producida por el virus IPN. La distancia entre el fondo de la balsa y el sitio de muestreo fue de al menos $3 \mathrm{~m}$.

\section{PROTOCOLO DE EXTRACCION DE VIRUS DESDE LOS SEDIMENTOS}

Los sedimentos de campo fueron obtenidos con una draga, colectándose una capa superficial de aproximadamente $5 \mathrm{~cm}$. Dos sitios diferentes, con tres submuestras sedimentarias para cada caso. Las muestras fueron mantenidas a temperaturas inferiores a $10{ }^{\circ} \mathrm{C}$, hasta su procesamiento en el laboratorio. A $4 \mathrm{~g}$ de sedimentos, a los cuales se les descarta el agua de poro, tal cual fue descrito anteriormente, se les agregaron $3 \mathrm{ml}$ de pirofosfato sódico 40 $\mathrm{mM}$ en PBS. Tras incubar por $15 \mathrm{~min}$, las muestras fueron sonicadas (Sonicador Bransonic, $125 \mathrm{~W}, 60 \mathrm{~Hz}$ ) durante 5 min en hielo para prevenir calentamiento, a continuación se agitaron manualmente por un minuto y se centrifugaron a $1020 \mathrm{x} g$ durante $5 \mathrm{~min}$. El sobrenadante, de cada muestra, se transfirió cuidadosamente a un microtubo de plástico estéril. Las muestras se titularon mediante el método de los focos fluorescentes (Espinoza y Kuznar 2002). Para optimizar la recuperación de virus desde las muestras de campo se tomaron $20 \mu \mathrm{l}$ del sobrenadante y sin filtración previa se aplicaron directamente sobre las células en cultivo. Las células infectadas se visualizaron tal cual fue descrito anteriormente.

\section{RESULTADOS Y DISCUSION}

Para investigar la supervivencia del virus IPN en sedimentos lacustres naturales, sedimentos conteniendo virus fueron mantenidos a $4{ }^{\circ} \mathrm{C}$ en tubos individuales durante diferentes períodos de tiempo. Tras titular en cultivos celulares, los resultados se examinaron en un microscopio de epifluorescencia. En la figura 1 se aprecia que en estas condiciones el virus permanece activo por al menos tres semanas. Así se establece que los sedimentos pueden, efectivamente, actuar como reservorios del virus IPN.

En la figura 2 se muestra que virus IPN puede encontrarse en sedimentos lacustres provenientes de sitios en los cuales se cultiva salmón y que además tienen una historia previa de brotes de la enfermedad viral. El método de extracción permitió la detección de 75 FF / g de sedimento en cada una de las dos muestras analizadas. No fue posible, en cambio, recuperar virus desde sedimentos provenientes de sitios sin una historia previa reciente de brotes con virus IPN.

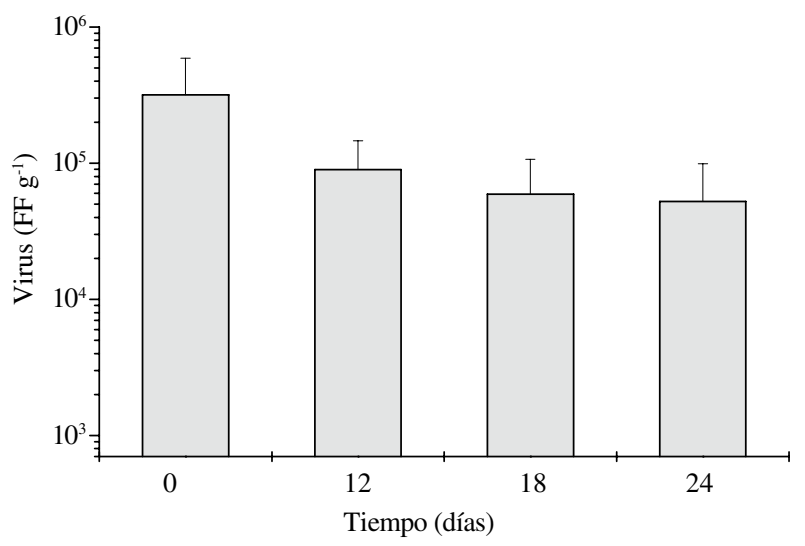

Figura 1. Recuperación de virus IPN incorporado a sedimentos de agua dulce y mantenidos hasta 24 días antes de titular, $\mathrm{n}=3$.

Recovery of IPNV seeded onto freshwater sediments and maintained up to 24 days before titration, $n=3$. 


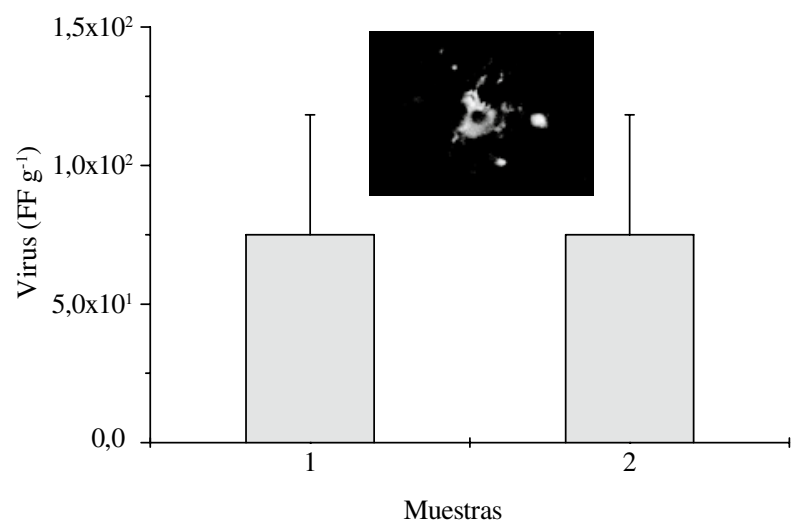

Figura 2. Muestras de campo positivas para virus IPN. Los sedimentos fueron extraídos con pirofosfato y titulados en células-CHSE 214. Las células infectadas fueron visualizadas mediante inmunofluorescencia (inserción, una célula central con abundante marca citoplasmática, 1000X) y contadas como FF.

IPNV positive field samples. The sediments were extracted with pyrophosphate and titrated in CHSE-214 cells. Infected cells were visualized by immunofluorescence (inlet, one central cell with abundant cytoplasmatic labeling, 1000X) and counted as FF.

Estos resultados, aunque de carácter exploratorio, demuestran la potencial importancia de los sedimentos respecto de la diseminación del virus IPN en un ambiente acuático. Los virus en estos reservorios pueden tener una vida bastante larga. Virus que infectan algas, por ejemplo, pueden permanecer activos en los sedimentos por un período superior a tres meses (Nagasaki y col 2004). Si bien no se conoce cuánto tiempo más allá de tres semanas el virus IPN puede permanecer activo en un sedimento, sí se conoce que el virus es muy resistente a los factores ambientales y que puede permanecer viable en agua de mar durante varios meses (Mortensen y col 1998), por lo tanto, es razonable pensar que el virus presente en los sedimentos es un riesgo para los animales en jaulas-balsa y también para las especies nativas.

Para iniciar un brote de la enfermedad se requieren como mínimo concentraciones de virus desde las 100 UFP / L (McAllister y Bebak 1997). En investigaciones futuras se debería analizar si es posible obtener tales concentraciones de virus mediante la agitación natural o forzada de sedimentos aislados de sitios con historias previas de virus IPN. Esta investigación es relevante en cuanto a demostrar que el sedimento puede servir de reservorio para la diseminación del virus durante una eventual resuspensión del material. Es necesario efectuar posteriores investigaciones para determinar el rol de los diferentes mecanismos involucrados en la liberación de virus desde sedimentos, entre ellos instalaciones y/o procedimientos de limpieza, surgencia y otros eventos oceanográficos y climáticos. El procedimiento descrito en este trabajo puede ser usado como herramienta para detectar potenciales focos de infección para peces y otras especies susceptibles al virus IPN, tanto en centros de cultivo como en ambientes naturales.

\section{RESUMEN}

El virus de la necrosis pancreática infecciosa, virus IPN, es una preocupación constante para la industria de la salmonicultura. El agua es el vehículo más importante para la transmisión horizontal del virus, por lo tanto, los sedimentos próximos a las instalaciones de una piscicultura pueden convertirse en reservorios del virus. En este trabajo se presenta un método simple y práctico destinado a cuantificar virus en sedimentos de áreas en las cuales se cultivan salmones. El virus se extrae con una solución de pirofosfato sódico y se titula en células CHSE-214 mediante el método de los focos fluorescentes (FF). Los resultados mostraron que el virus puede permanecer activo durante semanas en los sedimentos y que, además, el virus puede detectarse en sedimentos obtenidos de ambientes con una historia previa de brotes de necrosis pancreática infecciosa.

\section{REFERENCIAS}

Chamorro C, JC Espinoza, K Soto, J Kuznar. 2006. Concentración del virus de la necrosis pancreática infecciosa mediante ultrafiltración de flujo tangencial combinado con filtración de exclusión. Arch Med Vet $38,77-82$.

Espinoza E, G Farias, M Soler, J Kuznar. 1985. Identity between infectious pancreatic necrosis virus VR-299 and a Chilean isolate. Intervirology 24, 58-60.

Espinoza JC, J Kuznar. 2002. Rapid simultaneous detection and quantitation of infectious pancreatic necrosis virus (IPNV). $J$ Virol Methods 105, 81-85

Lawrence JE, AM Chan, CA Suttle. 2002. Viruses causing lysis of the toxic bloom-forming algae Heterosigma akashiwo (Raphidophyceae) are widespread in coastal sediments of British Columbia, Canada. Limnol Oceanogr 47, 545-550.

Lewis GD, MW Loutit, FJ Austin. 1985. A method for detecting human enteroviruses in aquatic sediments. J Virol Methods 10, 153-162.

McAllister PE, J Bebak. 1997. Infectious pancreatic necrosis virus in the environment: relationship to effluent from aquaculture facilities. J Fish Diseases 20, 201-207.

Mortensen S, RK Nilsen, B Hjeltnes. 1998. Stability of an infectious pancreatic necrosis virus (IPNV) isolate stored under different laboratory conditions. Dis Aquat Organ 33, 67-71.

Nagasaki K, Y Tomaru, K Nakanishi, N Hata, N Katanozaka, MYamaguchi. 2004. Dynamics of Heterocapsa circularisquama (Dinophyceae) and its viruses in Ago Bay, Japan. Aquat Microb Ecol 34, 219-226.

Suttle CA, F Chen. 1992. Mechanisms and rates of decay of marine viruses in seawater. Appl Environ Microbiol 58, 3721-3729. 
